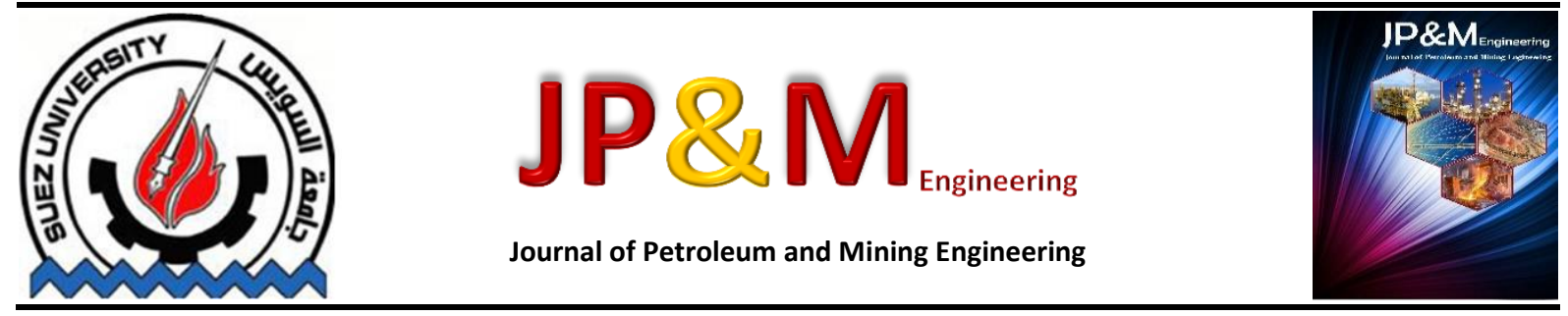

\title{
Studying Techniques of Gas Emission Reduction
}

\author{
G. M. Abdel-Aleem ${ }^{a}$, F. K. Gad ${ }^{a}$, W. B. Said ${ }^{b}$, H. A. Faroun ${ }^{c}$ \\ ${ }^{a}$ Faculty of Petroleum \& Mining Engineering, Suez University, Suez, Egypt \\ b British Petroleum \\ ${ }^{c}$ East Zait Petroleum
}

\section{Keywords}

Surfactant; Visco-Elastic.

\begin{abstract}
Traditionally in the Oil \& Gas industry, low pressure gas has been disposed of by flaring to atmosphere. Today this process is becoming increasingly unacceptable as the industry progresses towards eliminating the emission of greenhouse gases into the atmosphere whilst simultaneously conserving energy. Therefore, the demand for equipment that can safely and economically compress low pressure gas back into the production process is rapidly increasing. Ejectors are ideally suited to this application because they employ high-pressure gas energy to entrain and compress low pressure gas to a pressure where the gas can be recovered into production or used as fuel gas
\end{abstract}

\section{Introduction}

Flaring is a combustion process used to dispose of natural gases (sweet gas, sour gas, acid gas or other hydrocarbon) through a vertical stack. Facilities in the oil and gas industry may routinely flare small volumes of natural gas that are technically difficult and uneconomic to conserve. Flaring is also an important safety measure, used to safely dispose of natural gas that would otherwise pose a hazard to workers, nearby residents and facility equipment during nonroutine occurrences like emergencies, process upsets, equipment failure and power failure conditions. Flaring is recognized as an important issue for the upstream oil and gas industry for health, safety and environmental Impacts, as well as conservation of energy resources. Studying techniques of gas emission reduction by overcoming many technological barriers and non-availability of indigenous technology made the research all the more challenging, so this paper has taken Initiative

for the efficient use of natural resources and reduced the flaring of natural gas by offering alternative that provides the benefit of conservation of resources and reduction of emissions by recovering process vent gases, with often considerable high value, instead of flaring. In the past, when engineers designed jet ejectors, either a "rule-of-thumb" or "trialand-error" approach was used. Both approaches may provide unsatisfactory performance, and thus consume too much power, material, and labor. Although jet ejectors have been applied as thrust enhancers, they have mostly been restricted to aircrafts and rockets. They have not been used as gas compressors for flare gas recovery. Hence, with this motive, this paper takes up this challenge. Jet ejectors can potentially be used as thrust augmenters in an aerodynamic lifting body to create external characteristics that greatly augment aerodynamic lift [2-3]. Ejectors have been used on aircraft engines to increase the thrust of a primary propulsive nozzle, but also to mix the high-temperature exhaust flow with ambient air to provide lower jet noise and plume radiation [4]. With advances in science and technology, many new areas were identified for their application. Jet ejectors have been used in airconditioning systems [5], and also absorption systems [6]. Unfortunately, there are little publications available for the application of jet ejectors as a compressor used as flare gas recovery unit such as some broachers for Transvac Company that has over 40 years' experience supplying ejector solutions in oil and gas industry [7], this drives this study to make a fresh beginning in this field by performing theoretical study on gas ejector to provide answers to the problems left unsolved. With little background research materials available [8-9-10], the study started by performing a flare reduction plan including parametric study on gas ejector to generate proposed flared gas recovery unit [11-12]. Since the motivation of this research is to design a working ejector as a flared gas recovery unit that recycles all the technical flared gases otherwise being led to the flare system to put them back to the system in order to recover the valuable hydrocarbons and therefore reduce flaring to zero level, fig (1) illustrates the proposed flared gas recovery unit using gas ejector, so the present paper 
provide an example of flare gas recovery from low pressure well where an oil production operation has historically flared associated gas due to lack of infrastructure for natural gas processing as illustrated in fig (2). The purpose of the research is to:

a) Reduce the wastage of precious natural resources.

b) Reduce the impact on the environment and safety of the locality / surrounding areas.

c) Achieve zero hydrocarbon emissions.

d) Reduce the emissions of greenhouse gases (GHG)'s into the atmosphere.

e) Reducing consumption of natural gas by using recovered gas as fuel.

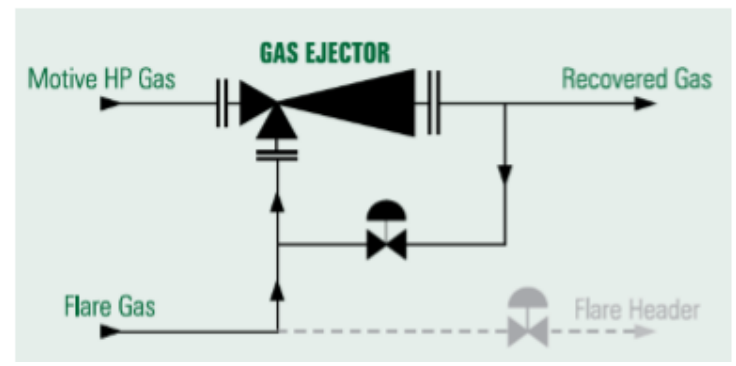

Figure 1. Flare gas recovery unit Using gas ejector.

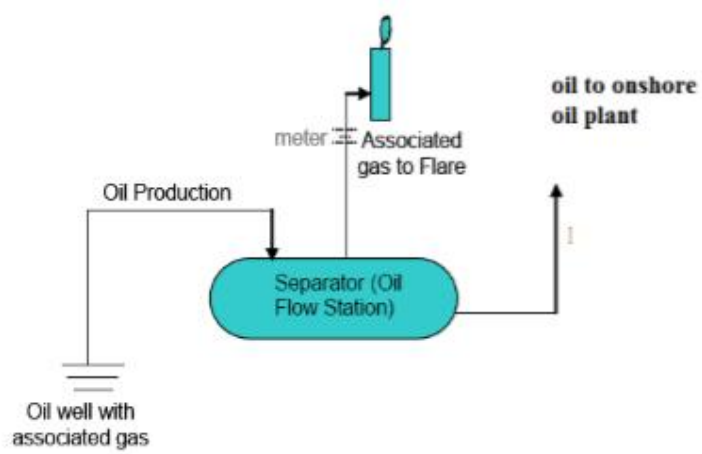

Figure 2. Baseline illustrations for case study.

Finally the research activity has therefore reduced the release of $\mathrm{CO} 2$ emissions into the atmosphere and has positively contributed to the fuel requirement of the country by providing additional source of fuel (gas). The research has promoted sustainable economic growth and enabled conservation of environment and natural resources, and the revenue generated from low pressure gas will also increase the economic sustainability, so this will encourage others to take similar environmentally friendly researches in the industry.

\section{Case Study of Flare Gas Recovery from Low Pressure Well}

The study collected data from East Zeit petroleum company-joint venture company between Egyptian General Petroleum Corporation (EGPC) and Dana Petroleum Company -which is the first Esso production facility in Egypt that was originally started up in 1985, in order to follow the world regulations and be environmental friends, the study provide an example of flare gas recovery from low pressure well.

\section{Before the study}

The oil and associated gas are produced from low pressure well (C-5) in the offshore oil field (platform C), and transported by gathering pipelines to an offshore existing oil flow station (platform A). At the flow station, the associated gas is separated from the oil and most of the gas is flared. The oil is shipped by pipeline to market. A total of 1.036 MMSCFD of gas is flared at the oil flow station.

\section{What is the study will change}

The study activity encompasses the recovery of the associated gas from the oil flow station by the design of flare gas recovery unit (FGRU) using gas ejector to entrain and compress waste gas to a pressure where the gas can be recovered into production. Fig (3) outlines the recommended steps for developing a flare reduction plan for a specific facility by using gas ejector; there are four main elements in the systematic approach:

1. Determine flare properties.

2. Gas ejector design.

3. Quantifying emission reduction.

4. Economic analysis and profitability measure.

The four elements are integral to each other and critical to the success of new technique.

\section{Gas jet ejector design for under investigation case study}

The basic idea of a gas ejector is to accelerate the motive flow to supersonic by a Converging-diverging nozzle, primary flow exit at the suction chamber where, secondary flow is induced by this high-velocity depressurized flow. In most cases, there is also a diffuser installed at the exit of the mixing section to induce pressure recovery.

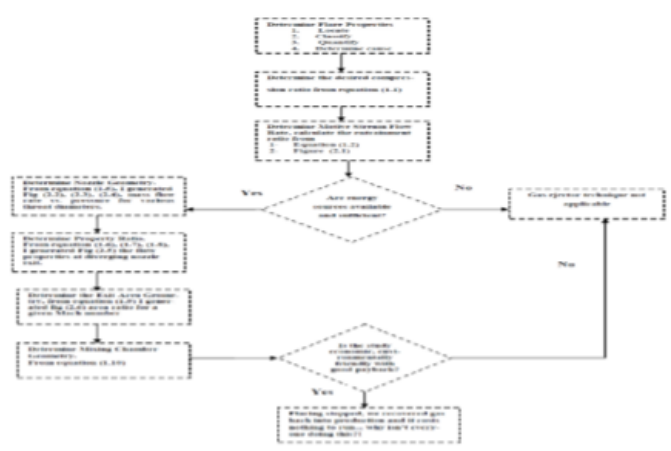

Figure 3. flow chart outlines the recommended steps for developing.

\section{The steps of a gas ejector design:}

1. Ejector operational conditions and flare conditions are collected from the East Zeit offshore oil fields and tabulated in Table 1.

2. The compression ratio (CR) is an important parameter in practical gas ejector design .it is desired to design an ejector which 
introduces more secondary flow and gain higher pressure recovery for the secondary flow. (CR) can be as higher as 4.0 if Entrainment ratio (ER) is extremely low, and it decreases sharply with the increase of (ER). $(C R)$ is below 1.2 when (ER) is more than 1 .

Gases from low pressure well will compressed from 60 Psi to pipeline pressure $130 \mathrm{Psi}$, so the desired compression ratio will be as follows;

$\mathrm{Cr}=\frac{\text { desired delivery pressure }}{\text { suction stream pressure }}$

$\mathrm{CR}=\frac{130}{60}=2.16667$

Consequently Entrainment Ratio (ER) can be estimated using the relationship between $C R$ and $E R$ from reference [1], so at $C R=2.16667$, $E R=10-0.95$. After calculating entrainment ratio, the maximum mass flow rate of motive stream can be calculated by equation (2).

$$
\begin{aligned}
& \mathrm{ER}=\frac{\text { mass flow rate of suction stream }}{\text { mass flow rate of motive stream }} \ldots . . . \\
& 10^{-0.95}=\frac{1973 \frac{\mathrm{LB}}{\mathrm{hr}}}{\text { mass flow rate of motive stream }}
\end{aligned}
$$

Mass flow rate of motive stream $=17584 \mathrm{LB} / \mathrm{hr}$. Molar flow rate of motive stream $=9.178$ MMSCFD The maximum mass flow rate through the system occurs when the flow is choked at the smallest area. This location is called the throat of the nozzle as illustrated in the schematic in fig (4) that clarify the basic component of gas ejector nozzle inlet section, throat section, and exit section (mixing chamber), the mass flow rate is maximum when Mach Number $(M=1)$, at these conditions flow is chocked.

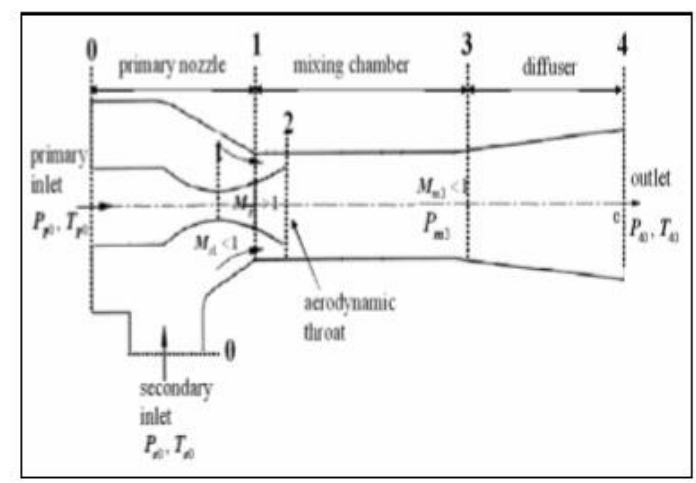

Figure 4. schematic of gas ejector model.

MACH NUMBER (M) A very important dimensionless parameter for compressible flow, specially, for supersonic flow Mach number is defined as the ratio of the fluid velocity to the local sonic speed.

$$
\mathrm{M}=\frac{\text { local fluid velocity }}{\text { local sonic speed }}=\frac{\mathrm{V}}{\mathrm{C}} \text {. }
$$

The local sound speed $\mathrm{c}$ in a medium with temperature $\mathrm{T}$ is given by:

$$
\mathrm{C}=\sqrt{\gamma \mathrm{RT}} \text {. }
$$

The mass flow equation (5) is quite "messy", so we will use a Java calculator that introduced by NATIONAL AERONAUTICS AND SPACE ADMINSTRATION (NASA)

$$
m_{p}=\frac{A_{1} P_{0}}{\sqrt{T_{0}}} \sqrt{\frac{\gamma_{p}}{R_{p}}\left(\frac{2}{\gamma_{p}+1}\right)^{\frac{\gamma_{p}+1}{\gamma_{p}-1}}}
$$

Table 1 : Flare and stream properties for case study

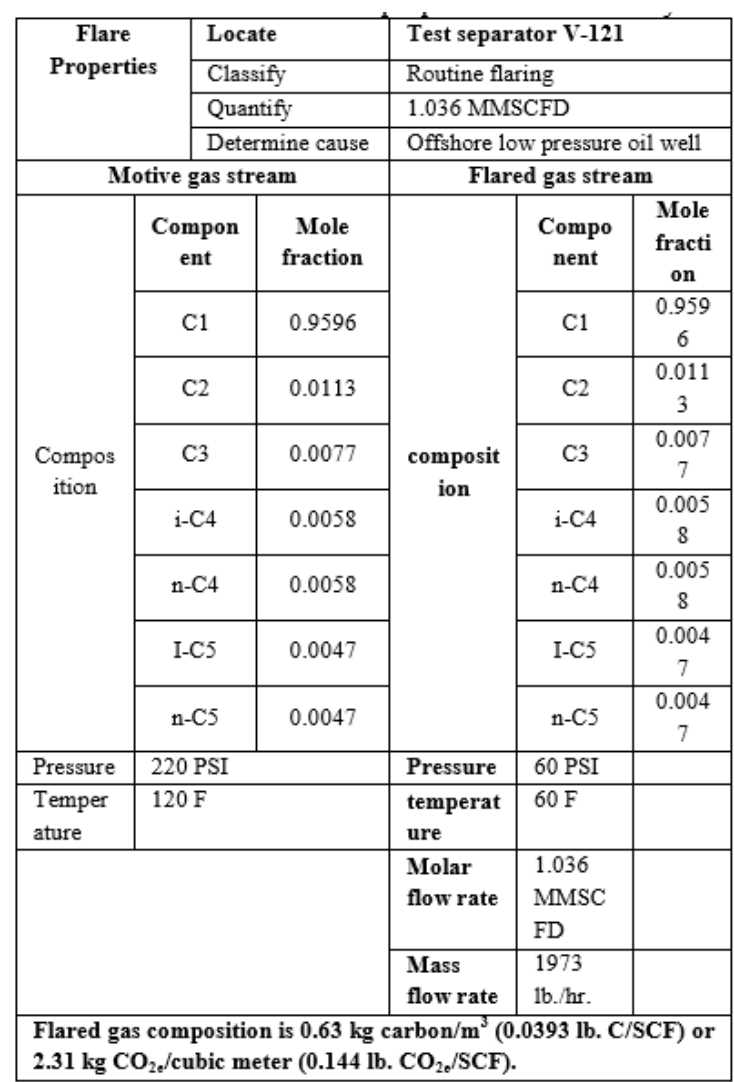

At the motive flow condition Pressure $=220$ PSI, Temperature $=60 \mathrm{~F}$, Specific heat ratio $=1.314$. Calculation of various throat areas with its maximum mass flow rate, to obtain the adequate throat area with the desired molar flow rate of the motive stream -Eq (5) - which calculated up in table (2) is so easy.

Table 2: nozzle throat area VS\& molar flow rate.

\begin{tabular}{|l|c|c|c|c|c|c|c|c|}
\hline $\begin{array}{l}\text { Nozzle } \\
\text { throat } \\
\text { area (Ft }\end{array}$ & 0.0 & 0.0 & 0.0 & 0.0 & 0.0 & 0.0 & 0.00 & $\begin{array}{c}0 . \\
00 \\
7\end{array}$ \\
\hline $\begin{array}{l}\text { Molar } \\
\text { flow rate }\end{array}$ & 5.4 & 6.1 & 6.7 & 7.4 & 8.1 & 8.6 & 9.10 & 9. \\
& 15 & 95 & 80 & 53 & 98 & 6 & $\begin{array}{c}51 \\
5\end{array}$ \\
\hline
\end{tabular}

Nozzle throat area (At) $=0.0067 \mathrm{ft} 2$ is to simulate the gas ejector on HYSYS software to get the nozzle exit Mach number, this HYSYS ejector simulation does a decent job of modeling ejectors, the mean reason for this simulation to calculate:

a) The mixing chamber pressure: From hysys shown in fig (5), various values of discharge pressure vise verse nozzle exit pressure can be calculated as shown in table (3), so at desired discharge pressure 130 psi, mixing chamber pressure $($ Pmix $=47 \mathrm{Psi}$, and from field data motive stream pressure $(\mathrm{Po})=220$ Psi.

b) The nozzle exit Mach Number: The local pressure, can be related with their 
corresponding values at primary condition by isentropic flow functions expressed in Equations (6);

Pressure: $\frac{P_{0}}{P}=\left(1+\frac{\gamma-1}{2} M^{2}\right)^{\frac{\gamma}{\gamma-1}}$

$\mathrm{Po}=220 \mathrm{Psi}$

$\mathrm{Po} / \mathrm{P}_{\operatorname{mix}}=\frac{220}{47}=4.68$

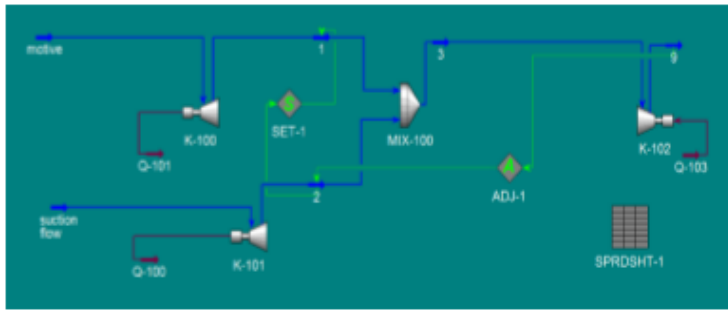

Figure 5. FGRU simulation on HYSYS.

Table 3: throat exit pressure VS discharge pressure.

\begin{tabular}{|l|c|c|c|c|c|c|c|c|}
\hline $\begin{array}{l}\text { Throat } \\
\text { exit (psi) }\end{array}$ & 29 & 31 & 35 & 37 & 40 & 43 & 46 & $\underline{\mathbf{4 7}}$ \\
\hline $\begin{array}{l}\text { Discharg } \\
\text { e(psi) }\end{array}$ & 110 & 112 & 117 & 119 & 122 & $\begin{array}{c}12 \\
5\end{array}$ & $\begin{array}{c}12 \\
8\end{array}$ & $\underline{\underline{\mathbf{P i p e}}}$ \\
\hline
\end{tabular}

Calculating the nozzle exit area, from the relation between $\mathrm{Me}=1.6$ and throttling nozzle area $=A *$ found to be $0.0067 \mathrm{ft} 2$ (Ref.1), and consequently exit area of the nozzle can be calculated as shown in table (4).

Table 4: Mach number VS Ae/At.

\begin{tabular}{|c|c|c|c|c|c|c|c|c|}
\hline $\begin{array}{l}\text { Mach } \\
\text { Number } \\
\text { (M) }\end{array}$ & 1 & 1.2 & 1.4 & $\underline{1.6}$ & 1.8 & 2.0 & 2.2 & 2.4 \\
\hline $\mathrm{A}_{\mathrm{N}} / \mathrm{A}_{\mathrm{t}}$ & 1 & $\begin{array}{c}1.0 \\
327 \\
\end{array}$ & $\begin{array}{l}1.1 \\
26 \\
\end{array}$ & $\frac{1.2}{80}$ & $\begin{array}{l}1.5 \\
03 \\
\end{array}$ & $\begin{array}{l}1.8 \\
11 \\
\end{array}$ & $\begin{array}{l}2.2 \\
25 \\
\end{array}$ & $\begin{array}{l}2.7 \\
73 \\
\end{array}$ \\
\hline$\frac{A_{e}}{A .}=\frac{1}{M}$ & $\frac{1+5}{1}$ & $\gamma-1$ & & ... & & & ... & (7) \\
\hline
\end{tabular}

\section{$\mathrm{A}_{\mathrm{e}}=0.0085 \mathrm{ft}^{2}$}

Determine property ratio at the nozzle exit for a given Mach number. The flow properties at the nozzle exit plane can be calculated using Equation (8), (9) and (10).

$$
\begin{aligned}
& \frac{T_{*}}{T_{0}}=\frac{2}{\gamma+1} \ldots \ldots . . . \\
& \frac{P_{*}}{P_{0}}=\left(\frac{2}{\gamma+1}\right)^{\frac{\gamma}{\gamma-1}} . \\
& \frac{\rho_{*}}{\rho_{0}}=\left(\frac{2}{\gamma+1}\right)^{\frac{1}{\gamma-1}} . .
\end{aligned}
$$

The results are tabulated in tables (5), (6),

\begin{tabular}{|c|c|c|c|c|c|c|c|c|}
\hline $\begin{array}{c}\text { Mach } \\
\text { number } \\
\text { (M) }\end{array}$ & 1 & 1.2 & 1.4 & $\underline{1.6}$ & 1.8 & 2.0 & 2.2 & 2.4 \\
\hline \multirow{2}{*}{$\mathrm{P}_{\mathrm{e}} / \mathrm{P}_{\mathrm{b}}$} & 0.5 & 0.4 & 0.3 & $\underline{0.2}$ & 0.1 & 0.1 & 0.0 & 0.06 \\
\hline & 52 & 34 & 32 & 48 & 81 & 31 & 939 & 6 \\
\hline \multirow{2}{*}{$\mathrm{T}_{\delta} / \mathrm{T}_{0}$} & 0.8 & 0.8 & 0.7 & $\underline{0.7}$ & 0.7 & 0.6 & 0.6 & 0.56 \\
\hline & 84 & 41 & 95 & $\overline{488}$ & 02 & 561 & 119 & 99 \\
\hline \multirow[b]{2}{*}{$\rho_{d} / \rho_{t}$} & 0.6 & 0.5 & 0.4 & $\underline{0.3}$ & 0.2 & 0.2 & 0.1 & 0.11 \\
\hline & 25 & 17 & 17 & 315 & 591 & 002 & 53 & 69 \\
\hline
\end{tabular}
respectively also shown in fig (6).

Table 5: Mach number VS property ratio .

\begin{tabular}{|c|c|c|c|c|}
\hline CR & 2.16667 & \multirow{3}{*}{$\begin{array}{c}\text { nozzle } \\
\text { geometry }\end{array}$} & $A_{t}$ & $\begin{array}{c}0.0067 \\
\mathrm{ft}^{2}\end{array}$ \\
\hline ER & $10^{-0.95}$ & & \multirow[b]{2}{*}{$A_{8}$} & \multirow{2}{*}{$\begin{array}{c}0.0085 \\
\mathrm{ft}^{2}\end{array}$} \\
\hline $\begin{array}{l}M_{p} \text { flow } \\
\text { rate }\end{array}$ & $\begin{array}{l}17584 \\
\text { lb. } / \mathrm{hr} .\end{array}$ & & & \\
\hline $\begin{array}{l}\mathrm{M}_{\mathrm{P}} \\
\text { Molar } \\
\text { flow rate }\end{array}$ & $\begin{array}{c}9.178 \\
\text { MMSCFD }\end{array}$ & \multirow{3}{*}{$\begin{array}{l}\text { nozzle exit } \\
\text { properties }\end{array}$} & $\mathbf{P}_{\mathrm{e}} / \mathbf{P}_{\mathrm{o}}$ & 0.2483 \\
\hline \multirow{2}{*}{$\begin{array}{l}\text { Mach } \\
\text { number }\end{array}$} & \multirow[t]{2}{*}{1.6} & & $\begin{array}{c}\mathrm{T}_{d} / \mathrm{T} \\
0\end{array}$ & 0.7488 \\
\hline & & & $\rho_{d} / \rho_{0}$ & 0.3315 \\
\hline
\end{tabular}

Table 6: gas jet ejector specs for case study.

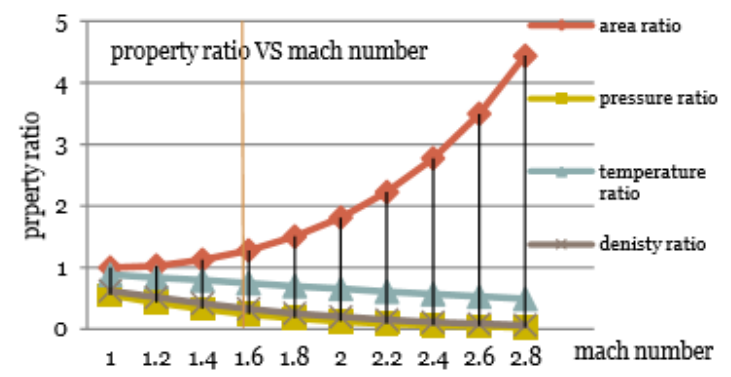

Figure 6. plot Mach number vs. \& property ratio.

\section{Quantifying Emission Reductions}

The following section demonstrates the emission estimation process for the baseline scenario and case study activity. Emission reductions are quantified as the difference between the baseline and project emissions, considering that each of vent emissions (vent), fugitive emissions (FUG) and indirect emissions (IND) are equal prior to and after the project. Study data Information (based on real, measured data from East Zeit Petroleum Company): 1.036 MSCFD of associated gas from low pressure well (C-5) is flared before the study. Flared gas composition is $0.63 \mathrm{~kg}$ carbon/m3 (0.0393 lb. /SCF) or $2.31 \mathrm{~kg} \mathrm{CO2e/cubic}$ meter (0.144 lb. CO2e/SCF).

\section{Baseline scenario emissions estimate}

COMBUSTION EMISSIONS (CMB1): The flare emissions, included as part of CMB1, are estimated based on the flare gas composition. It is assumed that the flared gas carbon is all converted to $\mathrm{CO} 2 . \mathrm{CMB1}=($ Meter volume $) \times$ (Flare gas composition $)=\frac{29352 \mathrm{m3}}{D a y} \times \frac{365 \text { days }}{y r} \times$ $\frac{2.31 \mathrm{Kg} \mathrm{CO} 2}{\mathrm{~m} 3} \times \frac{\text { tones } \mathrm{CO} 2}{1000 \mathrm{Kg}}=\mathbf{2 4 7 4 8 . 1 4}$ tones $\mathrm{CO}_{2 \mathrm{e}}$

BASELINE EMISSIONS=24748.14 tones CO2e. Case study under investigation emissions estimates

COMBUSTION EMISSIONS (CMB2): Under the project scenario, the quantity of associated gas flared will be reduced to $2 \%$ as a purge gas of the baseline amount, the annual $\mathrm{CO} 2$ emissions are calculated as follows:

$\mathrm{CMB} 2=($ purge
composition) $=\quad \begin{aligned} & \text { volume }) \times(\text { flare } \\ & \frac{.02 \times 29352 \mathrm{~m} 3}{d a y}\end{aligned} \times \frac{365 \text { days }}{y r} \times$
$\frac{2.31 \mathrm{Kg} \mathrm{CO} 2}{\mathrm{~m} 3} \times \frac{\text { tones } \mathrm{CO} 2}{1000 \mathrm{Kg}}=494.96$ tones $\mathrm{CO}_{2 \mathrm{e}}$


PROJECT EMISSIONS $=494.96$ tones CO2e. EMISSION REDUCTIONS = Baseline Emissions - Project Emissions $=24748.14-494.96=24253.18$ tones CO2e Table (7) cumulates the results obtained from the above calculation.

Table 7: emissions reduction for case study.

\begin{tabular}{|c|c|c|c|c|c|}
\hline \multirow{5}{*}{$\begin{array}{c}\text { Base } \\
\text { line } \\
\text { emissio } \\
n \\
\text { estimate }\end{array}$} & $\begin{array}{c}\text { CMB } \\
1 \\
\end{array}$ & $\begin{array}{c}24748.2 \text { ton } \\
\mathrm{CO}_{2} \mathrm{e}\end{array}$ & \multirow{5}{*}{$\begin{array}{c}\text { Projec } \\
t \\
\text { emissi } \\
\text { on } \\
\text { estima } \\
\text { te }\end{array}$} & $\begin{array}{c}\mathrm{CMB} \\
2 \\
\end{array}$ & $\begin{array}{c}494.96 \text { ton } \\
\mathrm{CO}_{2 e}\end{array}$ \\
\hline & $\begin{array}{c}\text { VEN } \\
\text { T } 1\end{array}$ & 0 & & $\begin{array}{c}\text { VEN } \\
\text { T } 2\end{array}$ & 0 \\
\hline & $\begin{array}{c}\text { FUG } \\
1\end{array}$ & 0 & & $\begin{array}{c}\text { FUG } \\
2\end{array}$ & 0 \\
\hline & IND 1 & 0 & & $\begin{array}{c}\text { IND } \\
2\end{array}$ & 0 \\
\hline & $\begin{array}{c}\text { TOT } \\
\text { AL }\end{array}$ & $\begin{array}{c}24748.2 \text { ton } \\
\mathrm{CO}_{2} \mathrm{e}\end{array}$ & & $\begin{array}{c}\text { TOT } \\
\text { AL }\end{array}$ & $\begin{array}{c}494.96 \text { ton } \\
\mathrm{CO}_{2} \mathrm{e}\end{array}$ \\
\hline Emissi & edu & & 24253 & $\mathrm{nCC}$ & \\
\hline
\end{tabular}

\section{Economic analysis}

1. Payback period (PBP) how long a project must operate to break even; ignores the time value of money.

2.

$\mathrm{PBP}=$

cost of investment

cash flow per period

$\mathrm{PBP}=\frac{1,708,010}{1,279,152}=1.335$ year $=16$ month.

3. Net Present Value (NPV) can be described as the "difference amount" between the sums of discounted: cash inflows and cash outflows. It compares the present value of money today to the present value of money in future, and can be calculated from equation (12);

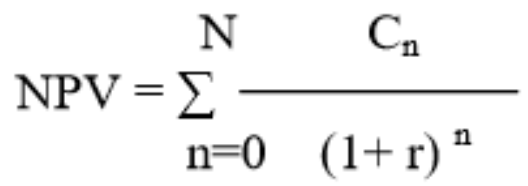

Where:

- $\quad \mathrm{N}$ is The total number of periods

- $\quad \mathrm{Cn}$ is the project cash flow.

- $\quad \mathrm{NPV}$ is the net present value of the project.

- $\quad r$ is the internal rate of return if NPV equals zero.

Note that the period is usually given in years, the study assume that the life time of the project will be five years.

- If $N P V>0$ the investment would add value to the firm and the project may be accepted.

- If $N P V<0$ the investment would subtract value to the firm and the project should be rejected.

4. Internal rate of return (IRR) is a rate of return used in capital budgeting to measure and compare the profitability of investments [11].

In more familiar terms, the IRR of an investment is the interest rate at which the costs of the investment lead to the benefits of the investment. This means that all gains from the investment are inherent to the time value of money and that the investment has a zero net present value at the interest rate. Mathematically, the IRR is defined as any rate of return ( $r$ ) that results in a NPV equal to zero in a series of cash flows. CALCULATION OF NPV \& IRR BY USING MICROSOFT EXCEL SPREADSHEETS: Easily by using EXCEL sheets from financial functions we can calculate NPV at any Discount rate NPV $=$ (rate, net inflow) + initial investment. In order to calculate the project net inflow we use the following equations:

Cash out $=$ CAPEX + OPEX Eq. (12)

Where:

- Capex is the capital expenditures "negative value ".

- Opex is the operating expenditures which equal to "Power cost, maintenance cost, utility consumption cost \& annual insurance expenses.

\section{Case study under investigation cost (cash out)}

1. COST OF PROCESS SHUT DOWN FOR TWO DAYS Total cost of process shut down $=$ Cost of deferred oil (8000 bbl. /day) + Cost of deferred gas MSCFD $)=1600000+10000=1610000 \$$.

2. COST OF THE EJECTOR $=45,000 \$$. From [10] by contacting Transvac sales representative.

3. INSTALLATION COST $=19530 \$$ From [9], chapter of cost estimation.

4. PERSONAL COST $=33,480 \$$ From [9], chapter of cost estimation. TOTAL COST OF THE PROJECT $=1708010 \$$. Table. 8 summarizes cash out for the first two years only after put FGRU in service.

TOTAL COST OF THE PROJECT $=1708010 \$$. Table. 8 summarizes cash out for the first two years only after put FGRU in service.

Table 8: Cash out for the two years after put FGRU in service.

\begin{tabular}{|c|c|c|c|c|c|c|c|c|}
\hline \multirow[b]{2}{*}{$\mathrm{n}$} & \multirow[b]{2}{*}{$\begin{array}{l}\text { CAP } \\
\text { EX }\end{array}$} & \multicolumn{6}{|c|}{ OPEX } & \multirow[b]{2}{*}{$\begin{array}{l}\text { Cash } \\
\text { Out }\end{array}$} \\
\hline & & $\begin{array}{l}\text { Opera } \\
\text { ting } \\
\text { Cost }\end{array}$ & $\begin{array}{l}\text { Mainte } \\
\text { nance } \\
\text { cost }\end{array}$ & $\begin{array}{l}\text { Shut } \\
\text { down } \\
\text { Cost }\end{array}$ & $\begin{array}{l}\text { Install } \\
\text { ation } \\
\text { cost }\end{array}$ & $\begin{array}{c}\text { Perso } \\
\text { nal } \\
\text { cost }\end{array}$ & $\begin{array}{l}\text { Total } \\
\text { OPEX }\end{array}$ & \\
\hline $\begin{array}{c}\text { ye } \\
\text { ar }\end{array}$ & $\begin{array}{c}\text { US } \\
\text { Syyea } \\
\mathrm{T}\end{array}$ & $\begin{array}{c}\text { US } \\
\text { Syea } \\
\text { r }\end{array}$ & $\begin{array}{c}\text { US } \\
\text { Siyear }\end{array}$ & $\begin{array}{c}\text { US } \\
\text { Syear }\end{array}$ & $\begin{array}{c}\text { US } \\
\text { Syear }\end{array}$ & $\begin{array}{c}\text { US } \\
\text { Syea } \\
\text { r }\end{array}$ & $\begin{array}{c}\text { US } \\
\$ \text { \$year }\end{array}$ & $\begin{array}{c}\text { US } \\
\text { S/year }\end{array}$ \\
\hline 0 & $\begin{array}{c}\$ 45,0 \\
00\end{array}$ & so & so & $\begin{array}{l}\$ 1,61 \\
0,000 \\
\end{array}$ & $\begin{array}{c}\$ 19,5 \\
3\end{array}$ & $\begin{array}{c}\$ 33,4 \\
8\end{array}$ & $\begin{array}{l}\$ 1,66 \\
3,010 \\
\end{array}$ & $\begin{array}{c}\$ 1,708 \\
, 010\end{array}$ \\
\hline $\mathrm{I}^{1+4}$ & 50 & 30 & so & 50 & 50 & 50 & so & so \\
\hline $2^{\text {nt }}$ & 50 & so & so & 50 & 30 & 30 & So & So \\
\hline
\end{tabular}

Case study under investigation returns (cash in)

Cash in = the price of buying the recovered gas after discount the taxes. Net inflow = Cash in - Cash out. Eq (14)

Net cash inflow tabulated in Table.9. Net present value of the project (N.P.V)

$\mathrm{NPV}=\frac{-1708010}{(1+0.12)^{\wedge} 0}+\sum_{i=1}^{5} \frac{831448}{(1+0.12)^{\wedge} i}$

$\mathrm{NPV}_{12} \%=1289173 \$$.

Internal rate of return of the project (IRR) And easily by drawing the NPV at different discount rates we can easily got the IRR which is the discount rate 
that given NPV equals to zero, IRR $=39 \%$ As shown in fig (7). Table 10 concludes all results obtained from the calculation of economic feasibility study.

Table 9: Net Cash Flow \& Cumulative profits for the two years after put FGRU in service.

\begin{tabular}{|c|c|c|c|c|c|c|c|}
\hline \multirow[b]{2}{*}{$\mathrm{n}$} & \multicolumn{4}{|c|}{ Cash In } & \multirow[b]{2}{*}{$\begin{array}{l}\text { Nes Cash } \\
\text { Flaw }\end{array}$} & \multirow[b]{2}{*}{ Taxes } & \multirow{2}{*}{$\begin{array}{l}\text { Net Cash } \\
\text { Flow } \\
\text { After taxes }\end{array}$} \\
\hline & $\begin{array}{c}\text { Morthly } \\
\text { \&as } \\
\text { necovered }\end{array}$ & $\begin{array}{l}\begin{array}{l}\text { herating } \\
\text { value }\end{array} \\
\text { a }\end{array}$ & $\begin{array}{l}\text { Gas } \\
\text { Prive }\end{array}$ & Cash tin & & & \\
\hline year & Lh'moxhl & Btalth. & US & US S/year & US s/year & $\underset{\text { US }}{\text { US }}$ & US \$ Syear \\
\hline 0 & so & \multirow{3}{*}{$2.131 \times 10^{4}$} & so & 0 & ${ }_{\$ 1,70 \times, 010}$ & 0 & ${ }_{\$ 1,70 \mathrm{~S}, 010}$ \\
\hline $1^{*}$ & 1429200 & & $\begin{array}{c}35 \\
\sin 10 \% \operatorname{cou}\end{array}$ & $\$ 1,279,152$ & $\$ 1,279152$ & $\$ 447703$ & 5831,448 \\
\hline $2^{2}$ & 14292100 & & $\begin{array}{l}3.5 \\
5 / 100 \times x\end{array}$ & $\$ 1,279152$ & $\$ 1,279152$ & 5447703 & $\$ 831,448$ \\
\hline
\end{tabular}

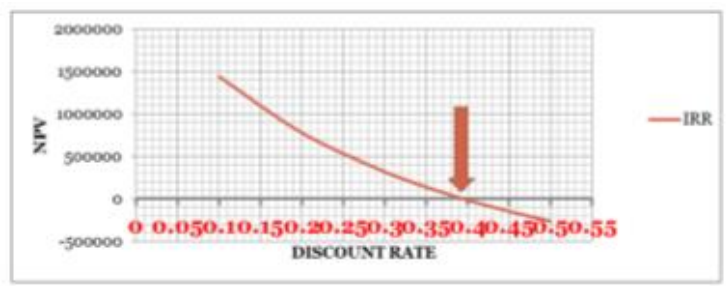

Figure 7. NPV vs. \& discount rate.

Table 10: economic feasibility study summery.

\begin{tabular}{|c|c|c|c|}
\hline \multicolumn{4}{|c|}{ Economic feasibility study } \\
\hline \multirow{6}{*}{$\begin{array}{l}\text { Basis data } \\
\text { assumptions }\end{array}$} & $\begin{array}{l}\text { Daily gas } \\
\text { recovered }\end{array}$ & 1.036 & MMSCFD \\
\hline & $\begin{array}{c}\text { Unit life } \\
\text { time }\end{array}$ & 5 & Years \\
\hline & $\begin{array}{c}\text { Operating } \\
\text { days }\end{array}$ & 330 & Day/year \\
\hline & $\begin{array}{l}\text { Discount } \\
\text { rate }\end{array}$ & 12 & $\%$ \\
\hline & Annual taxes & 32.5 & $\%$ \\
\hline & Capex & 45,000 & $\$$ \\
\hline \multirow{4}{*}{ Results } & $\begin{array}{l}\text { Daily gas } \\
\text { recovered }\end{array}$ & 1.0152 & MMSCFD \\
\hline & $\begin{array}{c}\text { Payback } \\
\text { period (PBP) }\end{array}$ & 16 & Month \\
\hline & $\begin{array}{c}\text { Net present } \\
\text { value } \\
\text { (N.P.V) }\end{array}$ & $1,289,173$ & $\$$ \\
\hline & $\begin{array}{c}\text { Internal rate } \\
\text { of return } \\
\text { (IRR) }\end{array}$ & $\begin{array}{c}39 \text { from fig } \\
\text { (7) }\end{array}$ & $\%$ \\
\hline
\end{tabular}

\section{Conclusion}

It is well known that there are many economical ways to achieve flaring minimization and gas conservation in oil and gas fields. In order to find these ways, a comprehensive process evaluation of plants, especially units that produce flare gases, comprehensive monitoring of flow and composition of flare gases, investigation of existing flare systems and finding alternative choices for reusing flare. Based on a comprehensive investigation, the study provided alternative to reduce gas flaring, by using gas jet ejector which is showing excellent performance to date, generating up to 1.036 MMSCFD of 'extra gases from low pressure wells. The ejector will pay for itself in less 16 months and production kicking in so easily. Advantages are also obtained from reduced flaring pollution, extended tip life, No maintenance No moving parts, Simple to control, Low cost \& weight ,Low noise levels and Safe to operate, Finally the flaring stopped, we recovered gas back into production and it costs nothing to run.

\section{References}

[1] Watanawanavet, S. , "Optimization of a HighEfficiency Jet Ejector by Computational Fluid Dynamic Software", MS thesis, Texas A\&M University, College Station, TX, 2005.

[2] Quinn, B. "A Wind Tunnel Investigation of the Forces Acting on an Ejector in Flight," ARL 700141, 1970

[3] Braden, R. P., Nagaraja, K. S., and von Ohain, H. J., "Ejector Workshop for Aerospace Application," AFWAL-TR-823059. AF-FDL, 1982.

[4] Mahalingam, R., and Glezer, A, "Design and Thermal Characteristics of a Synthetic Jet Ejector Heat Sink," Journal of Electronic Packaging, 127(2), pp. 172-177, 2005.

[5] Rogdakis, E. D., and Alexis, G. K., "Design and Parametric Investigation of an Ejector in an AirConditioning System," Applied Thermal Engineering, 20(2), pp. 213-226, 2000.

[6] Levy, A., Jelinek, M., and Borde, I. "Numerical Study on the Design Parameters of a Jet Ejector for Absorption Systems," Applied Energy, 72(2), pp. 467478, 2002.

[7] Transvac Systems Ltd., Mensal House, 1 Bramble Way, Alorton, Derbyshire, DE55 4RH, England Telephone: +44 (0) 1773831100 Facsimile: +44 (0) 1773831123 Registered in England No. 1526398

Email:sales@transvac.co.uk,Web:www.tra nsvac.co.uk

[8] American Petroleum Institute (API) and International Petroleum Industry Environmental Conservation Association (IPIECA). Oil and Natural Gas Industry Guidelines for Greenhouse Gas Reduction Projects .Prepared by URS Corporation, March 2007.

[9] CDM Executive Board. Clean Development Mechanism Project Design Document Form, "Flare Gas Recovery Project at Uran Plant, Oil and Natural Gas Corporation (ONGC) Limited," Registration Date 14 December 2007.

[10] Edgar,himelelbon,lasdon," optimization of chemical processes " second edition

[11] Moataz.E.Aly*, G.Abdelalem**, Eman.A.Emam**\& F.K.Gad**, "The Zero Continuous Flaring Technology", *Ugdc company, Port Saied, Egypt;**Faculty of Petroleum \&Mining Engineering, Suez, Egypt, 2012.

[12] Adel k.wasef, Abu Dhabi company (ADCO),"real zero gas flaring project in the middle east and gulf region", spe. 